\title{
Process mineralogy of bacterial oxidized gold ore in São Bento Mine (Brasil)
}

\author{
Marco Márquez ${ }^{\mathrm{a}, *}$ José Gaspar $^{\mathrm{b}}$, K.E. Bessler ${ }^{\mathrm{c}}$, G. Magela ${ }^{\mathrm{d}}$ \\ ${ }^{\text {a }}$ Faculty of Mines, National University of Colombia, Medellin, Colombia \\ ${ }^{\mathrm{b}}$ Geoscience Institute (IG), Brasilia University, Brazil \\ ${ }^{\mathrm{c}}$ Chemical Institute, Brasilia University, Brazil \\ ${ }^{\mathrm{d}}$ Exact Sciences and Biologic Institute (ICEB), Ouro Preto Federal University, Brazil
}

Available online 9 May 2006

\begin{abstract}
The São Bento deposit (Santa Bárbara, MG) occurs in the middle portion of the Quadrilátero Ferrífero (latu sensu), hosted by the São Bento iron formation. The most important minerals in the deposit are arsenopyrite, pyrrhotite, chalcopyrite, sphalerite, galena, electrum, magnetite, ilmenite, siderite, ankerite, calcite, quartz, chlorite, stilpnomelane and muscovite. A mineralogical characterization of samples from the bacterial oxidation process at the São Bento gold mine (MG) was performed using X-ray diffraction (XRD), Fourier transform infrared spectroscopy (FTIR), scanning electron microscopy with energy dispersive X-ray spectroscopy (SEM/EDS), Mössbauer spectroscopy and electron probe microanalysis (EPMA). Samples were collected in four different dates: one sample from the flotation concentrate and four from the bacterial oxidation system (BIOX) (TK2, TK4/TK68 bioreactors and TK28 thickener). Pyrrhotite was completely oxidized and arsenopyrite, pyrite and chalcopyrite were only slightly oxidized in the BIOX. Siderite occurs in small concentration in BIOX. Quartz, chlorite, and muscovite were slightly affected along the process. In BIOX, amoniumjarosite and hydroniumjarosite in lower abundance are the main phases formed. Native sulfur was detected in significant concentrations. Goethite and hematite are the main oxyhydroxides and an unidentified hydroxide containing up to $10 \mathrm{wt} . \% \mathrm{MgO}$ was observed. Subordinate phases in BIOX samples are fibroferrite, zykaite, bukovskyite, sarmientite, tooeleite, alunite and gypsum. Chemistry of the iron sulfates shows that there are two amoniumjarosites in the BIOX, high and lowAs jarosites. Low-As amoniumjarosite contains $10 \mathrm{wt} . \% \mathrm{As}_{2} \mathrm{O}_{5}$ in average; while the high-As one contains $20 \mathrm{wt} . \%$ As $\mathrm{O}_{5}$ in average. As-to-S substitution ratio is 1:1 suggesting a solid solution series toward an "As jarosite". Their crystallization seems to be controlled by a solvus.
\end{abstract}

(C) 2006 Elsevier B.V. All rights reserved.

Keywords: São Bento; Bacterial oxidized; Gold ore; X-ray diffraction (XRD)

\section{Introduction}

Mineralogical characterization of the products in different kinds of beneficiation processes, called "process mineralogy", was performed in a fundamental

\footnotetext{
* Corresponding author.

E-mail addresses: mmarquez@unalmed.edu.co (M. Márquez), gasp@unb.br (J. Gaspar).
}

key for the planning, optimization and monitoring in different types ores [1]. In this way, an appropriate understanding of the mineralogy in the ore and its transformation is essential to project and to operate any industrial system [2]. Characteristics like chemical composition, relative proportions, distribution, texture, types of intergrowths, size distribution, liberation degree and habits of different ore minerals and its products in the different stages of the process are very important to 


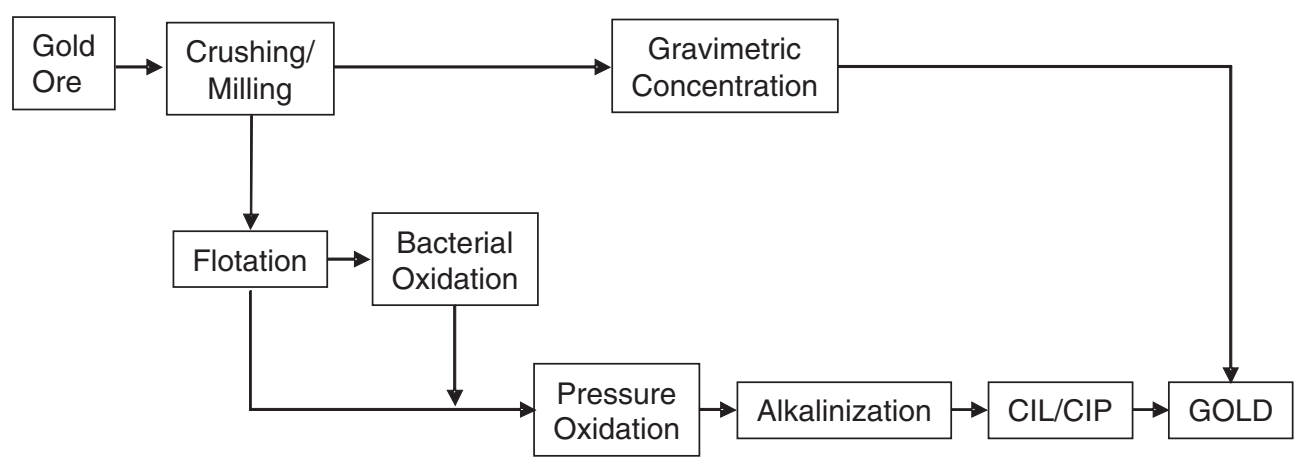

Fig. 1. Simplified flow chart of the São Bento gold system (modified from Da Silva et al. [8]).

the understanding of the different stages of the system, which allows to optimize the performance of processes, to improve the recovery, and/or to mitigate environmental problems. This type of research can be turned quite complicated due to factors like fine size of particles, low crystallinity, small proportion of mineral phases, and nature of ore minerals in the different steps of the process. Due to these features it is necessary to use different complementary analytical techniques like electron microscopes, electron microprobes, X-ray diffractometers and spectrometric methods (Mössbauer, infrared, etc.).

The São Bento deposit (Santa Bárbara, MG) occurs in the middle portion of the Quadrilátero Ferrífero (latu sensu), and is hosted by the São Bento iron formation. This is a BIF composed of fine layers of oxide, carbonate, silicate and sulfide facies. Sulfides usually form veins of variable sizes that crosscut the BIF layering at very small angles [3]. The ore is composed of pyrrhotite, arsenopyrite, pyrite, chalcopyrite, sphalerite, galena, electrum, magnetite, ilmenite, siderite, ankerite, calcite, quartz, chlorite, stilpnomelane and muscovite [4]. The most abundant sulfide minerals in the deposit are pyrrhotite and arsenopyrite, and pyrite in smaller proportions, around $50 \%, 40 \%$ and $10 \%$, respectively.

Gold crystals occur in different forms (a) small inclusions in arsenopyrite and pyrite, sometimes associated with pyrrhotite and gangue minerals; (b) large inclusions in pyrrhotite, usually in contact with arsenopyrite; (c) less frequently, in mineral interfaces or fractures, associated with sulfides or not; (d) rarely included in sphalerite or gangue minerals; (e) rarely filling cavities in arsenopyrite associated with galena, sphalerite, chalcopyrite, and pyrrhotite [5]. Electrum contains from 20 to 50 at.\% Ag. "Invisible" gold was analyzed by EPMA, SIMS, and/or SXRF mainly in arsenopyrite [5-7]. It was not possible to determine whether invisible gold occurs as structurally bonded atoms or as extremely small inclusions.

Due to the refractory characteristic of gold, the São Bento process consists of a two step oxidation pretreatment, a combination of bacterial and pressure oxidation (Fig. 1), with the purpose of releasing the fine gold present in the arsenopyrite and pyrite, mainly in the arsenopyrite.

The main objective of this research is to know the mineral phases generated in the bacterial oxidation process and to understand the evolution (transformation) of these phases, as a support to improve the process performance of the fine and invisible gold recovering.

\section{Materials and methods}

In order to characterize the phases generated during the biooxidation process, four samples were collected from the bio-reactors, named TK2, TK4 and TK-63-3, and from the thickener system (TK-28), in two different dates. Aiming to have standards for this research, Kjarosite, hydroniumjarosite, and amoniumjarosite were

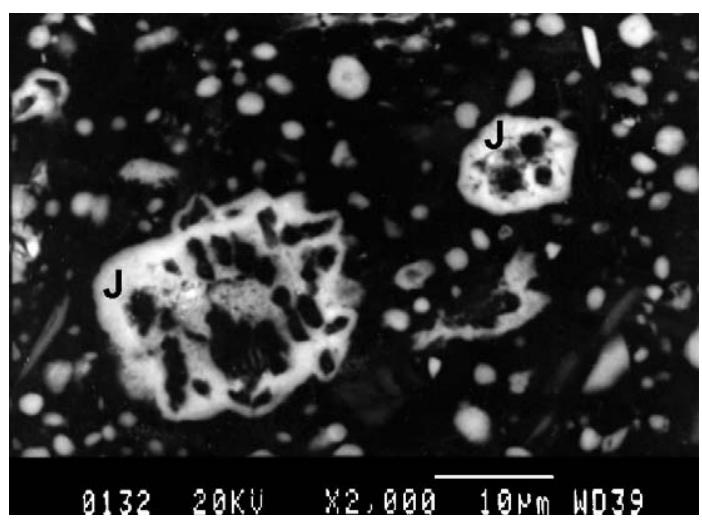

Fig. 2. SEM/BSE images. Typical J phase showing a porous texture. 


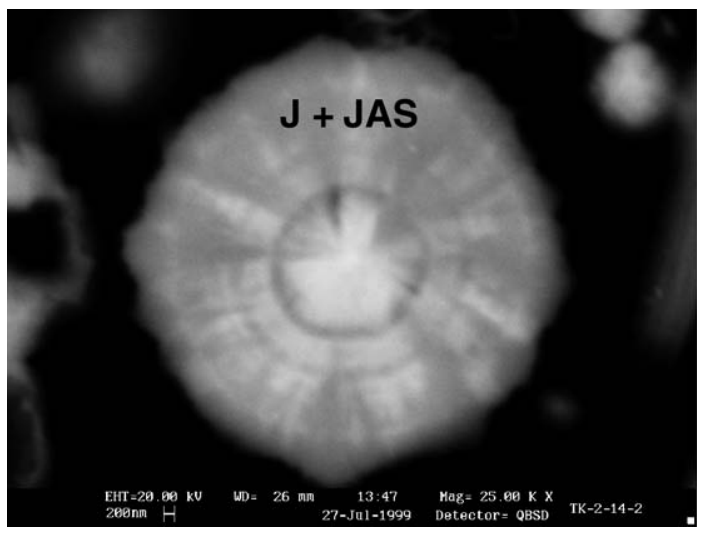

Fig. 3. Spheroidal radial texture in a grain of jarosite displaying mixture of J (darker gray) and JAS (lighter gray) phases.

synthesized using the method proposed by Dutrizac and Kaiman [9], as well as hydronium and ammoniumjarosite with different proportions of As.

A combination of analytical techniques was used to do the mineralogical characterization of the samples. Eight polished sections of each sample were prepared. Study of polished sections was performed with a JEOL JSM-840A scanning electron microscope in the backscattered electron mode and an energy dispersive X-ray detector. For the point chemical analyses, 102 analyses of the phase $\mathrm{J}$ (arsenic depleted jarosite) and 65 of the phase JAS (arsenic jarosite), a Cameca SX50 electron microprobe was used.

$\mathrm{X}$-ray diffraction (XRD) analyses were obtained in a Rigaku-GeigerFlex equipment, with $\mathrm{Cu} \mathrm{K} \alpha$ radiation, exited at $20 \mathrm{kV}$ and $40 \mathrm{~mA}$, utilizing graphite monochromator. The analysis were made using a step by step method, with a range of $2 \theta$ between $5^{\circ}$ and $75^{\circ}$, step of $0.02^{\circ}$ and a 5 -s counting time for step. The samples were crushed in an agate mortar, in acetone immersion, to avoid phase transformation. The Jade 3.0

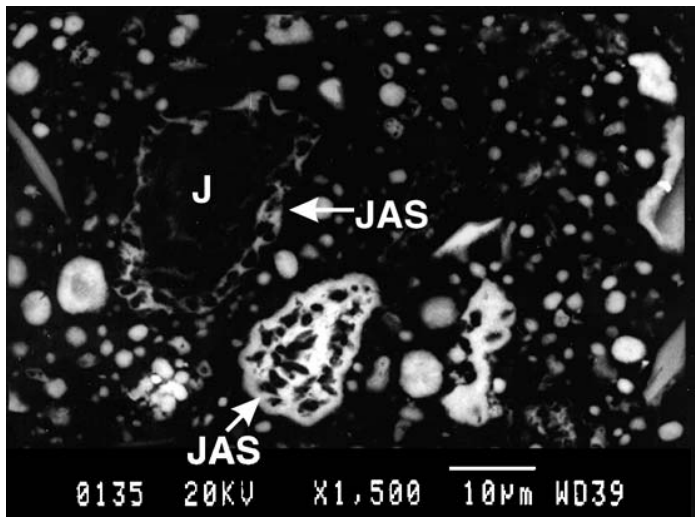

Fig. 4. Jarosite grain showing two generations of J and JAS phases.

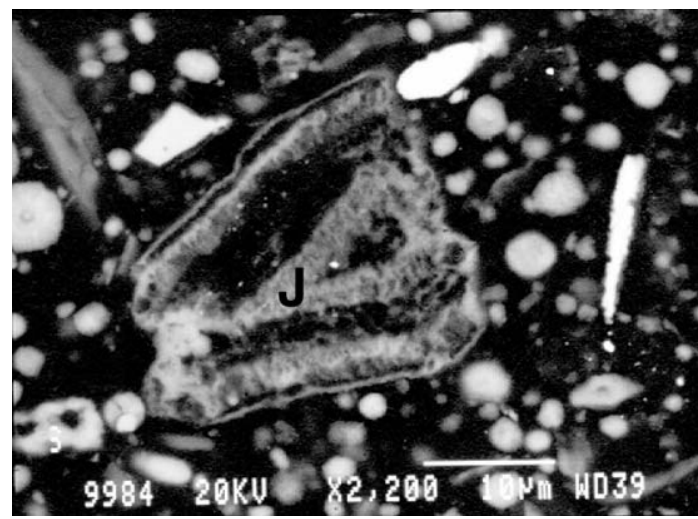

Fig. 5. Arsenopyrite pseudomorph composed of a jarosite-like phase.

for Windows with a PDF2 database was used for phase identification. Data from our different synthetic jarosite were also used for the interpretation of the results.

For the infrared spectroscopy analyses $2 \mathrm{mg}$ of sample and $150 \mathrm{mg}$ of $\mathrm{KBr}$ were used to do the pellets, which were heated to $100^{\circ} \mathrm{C}$ for $1 \mathrm{~h}$. The equipment was a Bomem MB infrared spectrometer, run for a $400-$ $4000 \mathrm{~cm}^{-1}$ spectral range, $4 \mathrm{~cm}^{-1}$ resolution and 20 scans per sample.

The Mössbauer spectroscopic analyses were obtained at room temperature $(297 \mathrm{~K})$ and LNT (liquid nitrogen temperature) $(77 \mathrm{~K})$, using a ${ }^{57} \mathrm{Co}$ source. The transmitted radiation were registered in a proportional counter and collected in a multichannel analyzer with 1024 channels. The spectra were folded and fitting used Lorentzian functions using a minimum square method. Result interpretation was performed with the MOSF free software, version PC V-1.0 (Laboratory of Magnetism Proeftuinstraat 86, B-9000 Ghent, Belgium). The samples were prepared mixing a $30-\mathrm{mg}$ sample to $\mathrm{BN}$ (99\%).

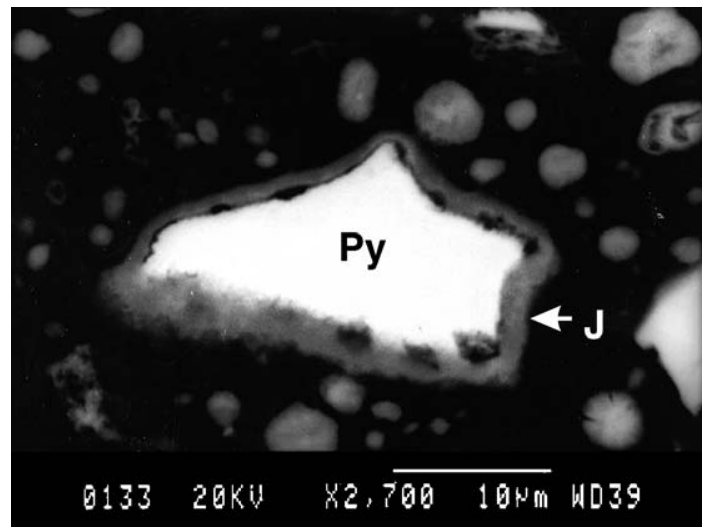

Fig. 6. J jarosite film covering pyrite (Py) crystal. 


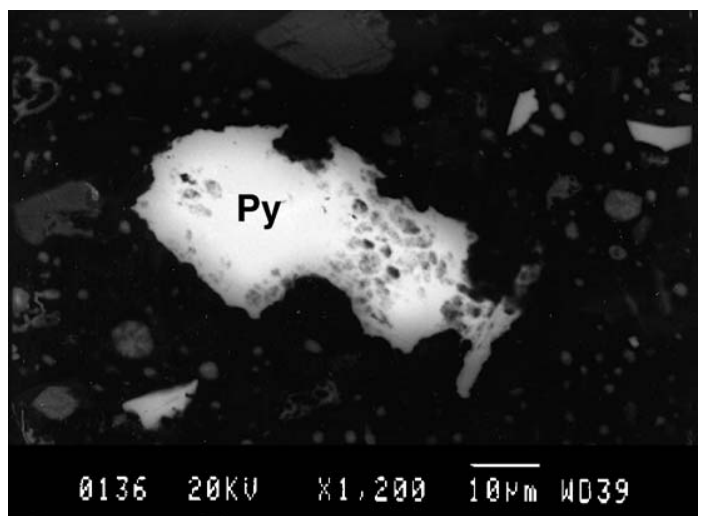

Fig. 7. Corroded pyrite grain.

The samples collected for mineralogical analyses have a statistical representation and the analyses performed by different techniques and on different grains for the same mineral give validity to the results.

\section{Results}

\subsection{Petrography}

Despite the large variety of textures their main features are as follows:

Jarosite shows different contents of As, resulting in different gray intensities in BSE images, where the higher-As content phases are clearer. The jarosite different types of textures are (i) porous anhedral grains, with sizes ranging between 20 and $30 \mu \mathrm{m}$ and irregular pores with diameters between 2 and $5 \mu \mathrm{m}$ (Fig. 2), sometimes smaller than $1 \mu \mathrm{m}$; (ii) rounded grains, sometimes with concentric radial texture (Fig. 3), displaying intergrowths among depleted- and rich-As regions, which may be radial or present coreedge limits with irregular patterns; (iii) rounded grains with a centered irregular pore, almost always As-depleted; (iv) particles showing

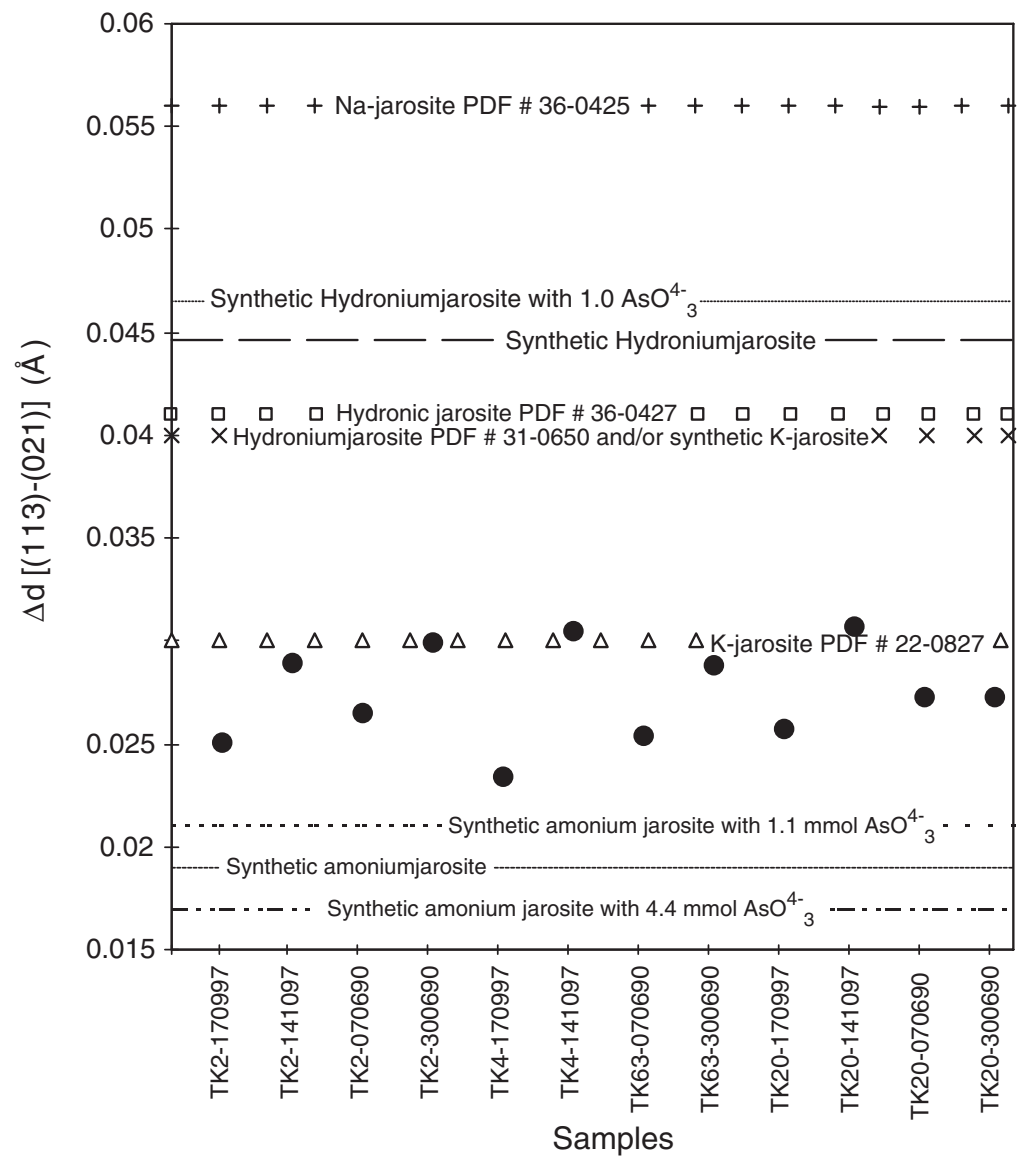

Fig. 8. São Bento BIOX jarosite in the $(\Delta d(\AA)[(113)-(021)])$ diagram for different jarosite classes. 


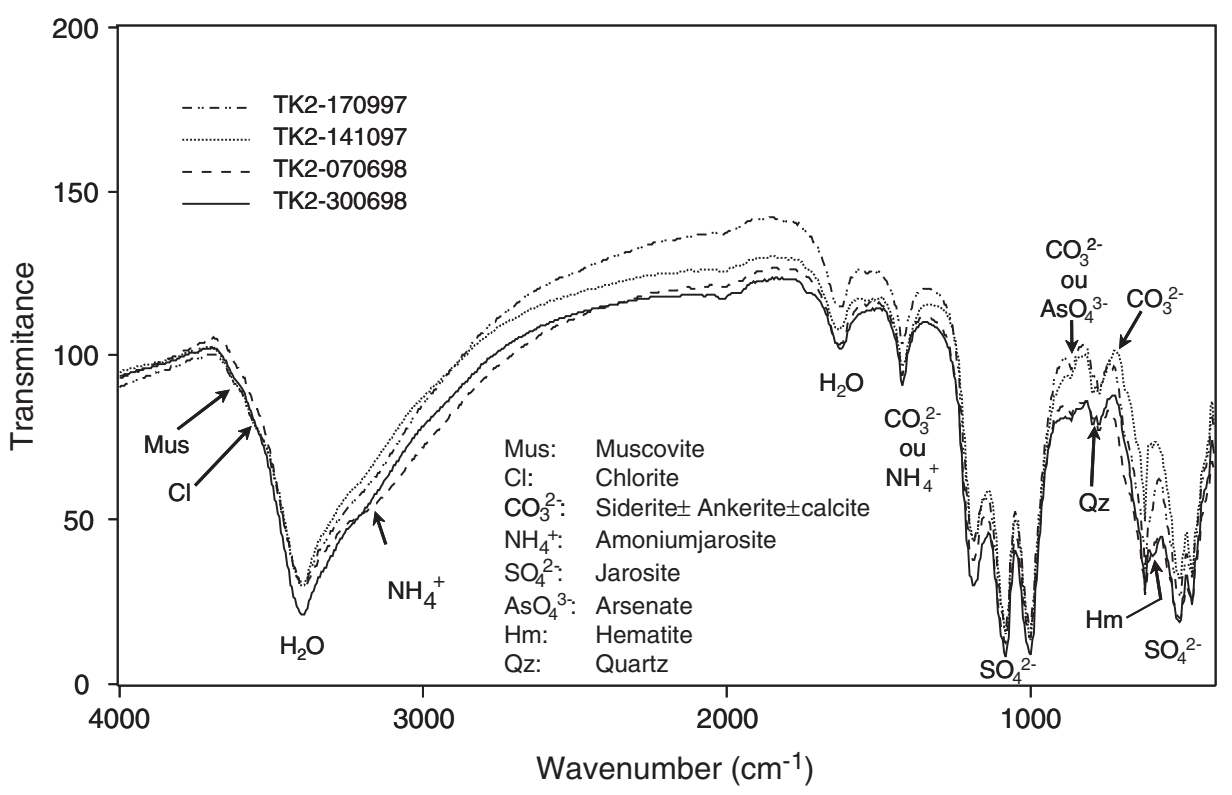

Fig. 9. FTIR spectra for the TK-2 bioreactor samples.

different stages of deposition (Fig. 4); (v) jarositelike arsenopyrite pseudomorph (Fig. 5), displaying As-depleted and As-rich phases intergrown; and (vi) thin films, almost always As-depleted, displaying thickness between 3 and less than $0.5 \mu \mathrm{m}$ on pyrite (Fig. 6), chalcopyrite, muscovite, quartz, chlorite and $\mathrm{Fe}$-oxyhydroxide grains.

Pyrite crystals, displaying typical corrosion textures (Fig. 7), often covered by jarosite thin films $(<3 \mu \mathrm{m})$.
Arsenopyrite grains, displaying typical corrosion textures, typically with no jarosite film.

Some minor sulfide minerals like chalcopyrite and sphalerite showing corrosion textures.

Minor quantities of Fe-oxyhydroxides, with minor contents of $\mathrm{Mg}, \mathrm{Ca}$, and $\mathrm{Mn}$, displaying anhedral or porous tabular habit.

Round elemental sulfur grains, showing intergrowth with As-rich and As-depleted jarosite.

Rare prismatic gypsum crystals.

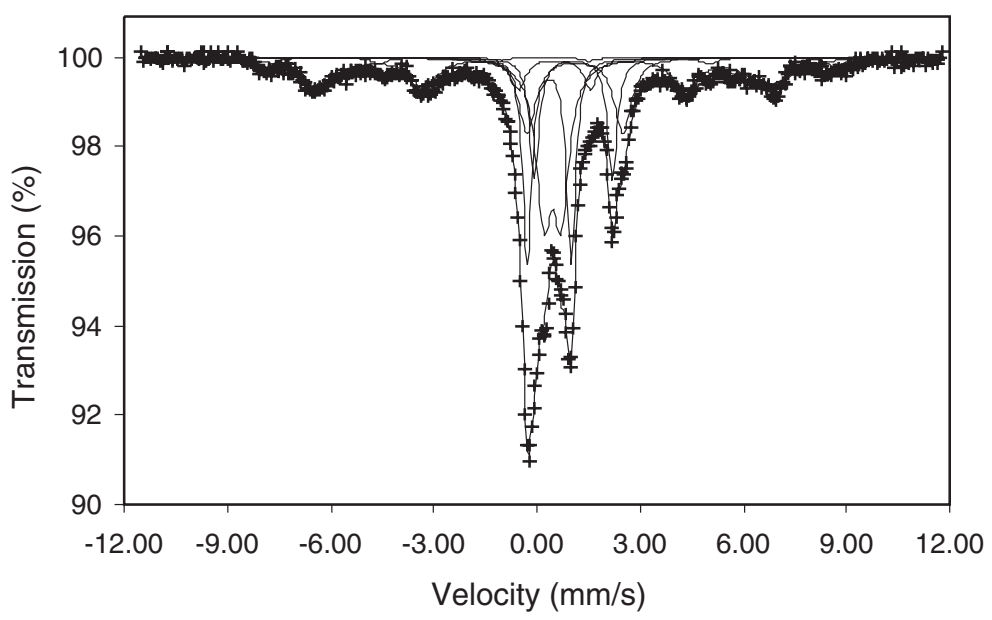

Fig. 10. LNT $\left(77^{\circ} \mathrm{C}\right)$ typical Mössbauer spectra of the bacterial oxidation product. 
Table 1

Hyperfine parameters resultant of the spectra fitting from the bacterial oxidation products

\begin{tabular}{llcll}
\hline Sample & \multicolumn{2}{l}{$77^{\circ} \mathrm{C}$} & Mineral \\
\cline { 2 - 4 } & IS $(\mathrm{mm} / \mathrm{s})$ & QS $(\mathrm{mm} / \mathrm{s})$ & HF $(\mathrm{T})$ & \\
\hline TK-2-300698 & 0.42 & 0.18 & 51.36 & Magnetite \\
& 0.46 & -0.34 & 40.64 & Superparamagnetic \\
& & & & goethite \\
& 0.47 & 1.27 & Jarosite \\
& 0.57 & 0.51 & Pyrite \\
1.22 & 2.78 & Chlorite \\
1.17 & 2.27 & & Siderite \\
\hline
\end{tabular}

LNT $\left(77^{\circ} \mathrm{K}\right)$. IS: isomer shift; QS: quadrupole splittings; HF: hyperfine magnetic field.

\subsection{X-ray diffraction (XRD), Fourier transform infra- red spectroscopy (FTIR) and Mössbauer spectroscopy}

From the results obtained by XRD, different types of iron sulfates, sulfoarsenates, oxides and hydroxides were detected, in addition to other resistant phases, which lasted after bacterial action. The most important identified minerals are:

(i) as the principal products of the bacterial oxidation process:

(a) amoniumjarosite, as preponderant phase, and elemental sulfur in minor quantities,

(b) in minor and trace quantities, along the whole process: fibroferrite $\left(\mathrm{FeSO}_{4}(\mathrm{OH}) .5 \mathrm{H}_{2} \mathrm{O}\right)$, sarmientite $\left(\mathrm{Fe}_{2}\left(\mathrm{AsO}_{4}\right)\left(\mathrm{SO}_{4}\right) \mathrm{OH} \cdot 5 \mathrm{H}_{2} \mathrm{O}\right)$, tooeleite $\left(\mathrm{Fe}_{8}\left(\mathrm{AsO}_{4}\right)_{6}(\mathrm{OH})_{6} \cdot 5 \mathrm{H}_{2} \mathrm{O}\right)$, hematite $\left(\mathrm{Fe}_{2} \mathrm{O}_{3}\right)$ and alunite $\left(\mathrm{KAl}_{3}\left(\mathrm{SO}_{4}\right)_{2}(\mathrm{OH})_{6}\right)$,

(c) in some samples, in minor and trace amounts: zykaite $\left(\mathrm{Fe}_{4}\left(\mathrm{AsO}_{4}\right)_{3}\left(\mathrm{SO}_{4}\right)(\mathrm{OH}) .15 \mathrm{H}_{2} \mathrm{O}\right)$, bukovskyite $\left(\mathrm{Fe}_{2}\left(\mathrm{AsO}_{4}\right)\left(\mathrm{SO}_{4}\right)(\mathrm{OH}) \cdot 7 \mathrm{H}_{2} \mathrm{O}\right)$,

(d) in trace quantities along the whole process: goethite $(\mathrm{FeO}(\mathrm{OH}))$

(e) gypsum, in considerable abundance in some samples or as minor, trace or non-existent in others;

(ii) as mineral phases resistant to the bioxidation process:

(a) pyrite, as the main sulfide, present in every sample, (b) arsenopyrite, identified in all samples in fair amounts, but much less abundant than pyrite,

(c) minor quantities of chalcopyrite,

(d) different types of silicates like quartz, chlorite, muscovite, in fair amounts, and stilpnomelane as trace,

(e) considerable proportions of magnetite, which may be a resistate or a neoformed mineral phase.

Using a modified method from Ivarson et al. [10] and Grishin et al. [11], and based on the observed shifts in the (021) and (113) reflections, due to the changes in the jarosite crystalline structure as a result from the entry of different cations in the A site, it was possible to state that the jarosite is the ammonic variety, in agreement with the entrance of arsenic in its structure (Fig. 8).

The results obtained by Fourier transform infrared spectroscopy (FTIR) (Fig. 9), in agreement with XRD, they show that the predominant mineral phase is jarosite, demonstrated by the presence of the bands $v_{3}$ (anti-symmetric stretching triply degenerate vibration: $1190 \mathrm{~cm}^{-1}, 1085 \mathrm{~cm}^{-1}$ and $1004 \mathrm{~cm}^{-1}$ ), $v_{4}$ (deformation vibration: $628 \mathrm{~cm}^{-1}$ ) and $v_{2}$ (deformation vibration doubly degenerate: $516 \mathrm{~cm}^{-1}$ and $475 \mathrm{~cm}^{-1}$ ) [12]. In addition, it could be observed typical bands of quartz (798 $\mathrm{cm}^{-1}, 778 \mathrm{~cm}^{-1}$ and $694 \mathrm{~cm}^{-1}$ ), muscovite $\left(\mathrm{OH}^{-} \mathrm{Al}\right.$ stretching: $\left.3624 \mathrm{~cm}^{-1}\right)$, chlorite $\left(\mathrm{OH}^{-}(\mathrm{Fe}-\right.$ $\mathrm{Mg}$ ) stretching: $\left.3551 \mathrm{~cm}^{-1}\right)$, and hematite $\left(660 \mathrm{~cm}^{-1}\right)$. Also there are absorptions in $740 \mathrm{~cm}^{-1}, 870 \mathrm{~cm}^{-1}$ and $1424 \mathrm{~cm}^{-1}$, corresponding to $v_{4}$ vibration of siderite, $v_{2}$ in siderite or $\mathrm{As}_{2} \mathrm{O}_{4}^{3-}$ in jarosite [13] and $v_{3}$ in jarosite or $\mathrm{NH}^{4+}$ in ammoniumjarosite [13-15], respectively.

Mössbauer results are brought about the iron mineral phases: jarosite, pyrite, chlorite, siderite, magnetite, siderite and superparamagnetic goethite are shown in Fig. 10 and their hyperfine parameters in Table 1.

\subsection{Mineral chemistry}

SEM/EDX results defined the formulae to the Asrich (JAS) and As-depleted jarosite (J), considering the solid solution substitution of elements in jarosite as discussed by Scott [16], Dutrizac et al. [17], Kubiz [18],

Table 2

Formulae obtained by a normalization of $X=2: X=\mathrm{S}+\mathrm{As}+\mathrm{Si}+\mathrm{P}$

\begin{tabular}{|c|c|c|c|c|c|c|c|c|c|c|c|}
\hline n.i.f. & $\mathrm{S}$ & $\mathrm{Fe}$ & As & $\mathrm{Si}$ & $\mathrm{Ca}$ & $\mathrm{Al}$ & K & $\mathrm{P}$ & $\mathrm{Na}$ & $\mathrm{Cu}$ & $\mathrm{Zn}$ \\
\hline $\mathrm{J}$ phase & 1.354 & 3.083 & 0.589 & 0.047 & 0.009 & 0.026 & 0.095 & 0.010 & 0.011 & 0.002 & 0.003 \\
\hline JAS phase & 0.965 & 2.814 & 0.996 & 0.028 & 0.006 & 0.016 & 0.055 & 0.011 & 0.009 & 0.001 & 0.003 \\
\hline
\end{tabular}

n.i.f.: number of ions per formula. 
Table 3

Sum for the different crystalographic sites in J and JAS, normalization $X=2$

\begin{tabular}{lllllll}
\hline n.i.f. & $X$ & $\mathrm{~B}$ & $\mathrm{~A}$ & $\mathrm{H}_{3} \mathrm{O}^{+}, \mathrm{NH}_{4}^{+}$ & $\mathrm{H}_{2} \mathrm{O}$ & $\mathrm{OH}^{-}$ \\
\hline J phase & 2.000 & 3.114 & 0.115 & 0.885 & 0.683 & 5.317 \\
JAS phase & 2.000 & 2.834 & 0.070 & 0.930 & 1.223 & 4.777 \\
\hline
\end{tabular}

n.i.f.: number of ions per formula.

$X=\mathrm{S}+\mathrm{As}+\mathrm{Si}+\mathrm{P} ; B=\mathrm{Fe}+\mathrm{Al}+\mathrm{Cu}+\mathrm{Zn} ; A=\mathrm{K}+\mathrm{Na}+\mathrm{Ca}$.

Dutrizac and Kaiman [9], Alpers et al. [19] and Rippmeester et al. [20]. Normalization was based on $X=2$, where $X$ corresponds to the sum of the elements that enter the sulfur site (Tables 2 and 3 ).

\section{Discussion and conclusion}

From the results previously outlined, it is possible to conclude that the oxidation process of different sulfide minerals, pyrrhotite was almost fully oxidized, with only traces of it, showing that it is the least resistant, which agrees with the observation of Rimstidt et al. [21]. Arsenopyrite is partially oxidized in the system, showing relicts with clear features of corrosion. Pyrite is only slightly oxidized, showing only some grains containing corrosion like gulfs.

It was possible to define two different mechanisms from bacterial oxidation of arsenopyrite and pyrite. Arsenopyrite was oxidized in-situ as demonstrated by its pseudomorfs. Pyrite underwent an oxidation by dissolution, due to the direct or indirect action of the bacteria, as shown by the corrosion gulfs, as observed by Ossa and Marquez [22] in the bacterial oxidation process at the "El Zancudo" mine (Colombia). The jarosite films observed commonly on pyrite grains, but not in arsenopyrite, were interpreted as an evidence of the passive behavior of pyrite during the process. This interpretation is supported by the fact that these films were observed on minerals typically passive in this type of process, as chlorite, quartz and muscovite [13].

In the bacterial oxidation process, the silicates did not present detectable changes, demonstrating refractoriness to it. Siderite is present and calcite is absent in the samples, in agreement with Deer et al. [23] and Márquez-Godoy [13].

Jarosite is the most abundant mineral phase as product of the bacterial oxidation of the sulfides in the Sao Bento gold ore. There is a predominance of the ammonic component in the jarosite. The generation of ammonium jarosite in bacterial systems has been already documented in the literature [11,14,15,24-29]. Ivarson et al. [10] produced jarosite using $A$. ferrooxidans and demonstrated the preference in the incorporation of $\mathrm{K}^{+}$and $\mathrm{NH}_{4}^{+}$in the jarosite in this system.

Ammonium in the jarosite was incorporated probably from compounds of ammonium which are used as nutrients in these processes, since it is the case of the

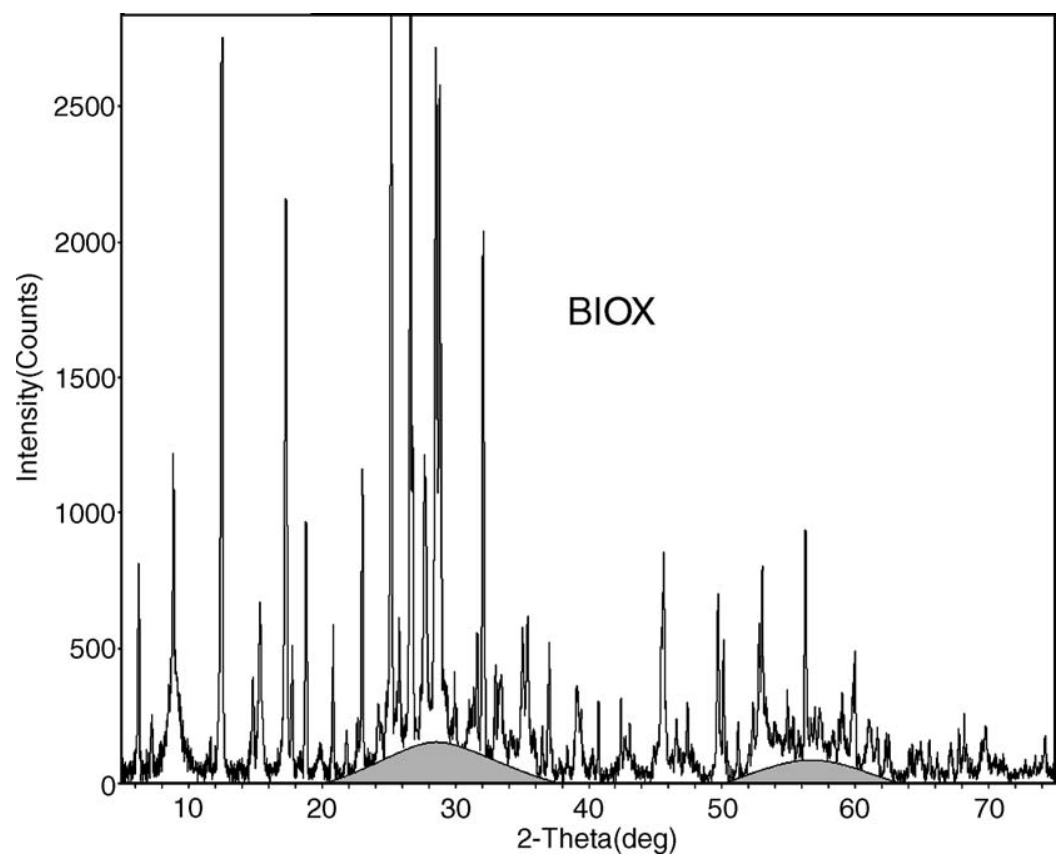

Fig. 11. Typical X-ray diffractogram of the bacterial oxidation process, showing the presence of amorphous iron arsenate (shaded), in agreement with the interpretation of Tuovinen et al. [33]. 
ammonium sulfate added in $9 \mathrm{~K}$ and $\mathrm{T} \& \mathrm{~K}$ as source of energy $[2,30,31] . K$ is very low in the São Bento jarosite, which is probably due to an effect of inhibition in the liberation of interlayer $\mathrm{K}$ in muscovite by the high ammonia concentration of the system [26]. There exists the possibility of a physical mixture between ammoniumjarosite and hydroniumjarosite, however, our data better support the occurrence of a solid solution series, according to information from Ivarson et al. [10] on how to distinguish both.

Jarosite may be As-rich (JAS) or As-poor (J). The JAS phase corresponds to a jarosite that presents a small shortcoming in the B site, small proportions of cations in the A site and a higher quantity of $\mathrm{H}_{2} \mathrm{O}$, compared to the $\mathrm{J}$ phase. On the other hand, the $\mathrm{J}$ phase presents a stoichiometric problem, corresponding to an excess of iron in the B site, which was interpreted as a possible intergrowth of iron oxyhydroxide. A 1:1 replacement relation was observed for S and As in both J and JAS. Crystalline iron arsenate phases were not detected. Nevertheless, there exists the possibility that arsenates occur as amorphous phases, which might be tiny intergrowth with jarosite, according to some XRD results (Fig. 11), as already found by Dutrizac et al. [17], Dutrizac and Jambor [32] and Tuovinen et al. [33]. Another possibility is the adsorption of $\mathrm{AsO}_{4}^{3-}$ in the jarosite grains or another amorphous phase mechanically mixed up (as it might happen with some iron oxihydroxide). This would account for the EPMA results. So, arsenic might adsorb on iron oxihydroxides. On the other hand, according to Jones et al. [34] the adsorption of arsenic in iron oxihydroxides depends on $\mathrm{pH}$, diminishing as $\mathrm{pH}$ increases, in agreement with the conditions in bacterial oxidation processes.

The substitution of sulfur by arsenic in several classes of jarosite $\left(\mathrm{K}^{+}, \mathrm{Na}^{+}, \mathrm{NH}_{4}^{+}\right.$and $\left.\mathrm{Pb}^{2+}\right)$ has been established by the presence of $\mathrm{AsO}_{4}^{3-}$ in the $\mathrm{SO}_{4}^{2-}$ site, but only in small amounts (maximum of $4 \mathrm{wt} . \%$ ), without changes in the unit cell parameters [17,32]. According to Dutrizac et al. [17] there are two mechanisms that accommodate the larger charge of the arsenate in the jarosite structure; the first, based on the generation of $\mathrm{HAsO}_{4}^{2-}$ (or $\mathrm{AsO}_{3} \mathrm{OH}^{2-}$ ), with a similar charge of sulfate and, the second by balancing the excess of charge by turning $\mathrm{OH}^{-}$ions into water.

This type of discussion is of great relevance, principally bearing in mind the following facts: (i) the narrow and common relation that exists between sulfides (pyrite, pyrrhotite and less frequently marcasite, mackinawite) and As sulfosalts (arsenopyrite and less commonly tennantite, lollingite, enargite, realgar and orpiment) in systems of natural or artificial oxidation, be it or not by the catalytic action of the bacteria; (ii) the high acid levels reached in diverse types of hydrometalurgic processes and in acid drainages $[2,25,35-38]$, where some phases may precipitate the arsenate as with the case of scorodite $[26,33,39-43]$. These phases do not precipitate easily and are not completely stable $[40,44,45]$, generating potential danger for the environment; (iii) Scorodite is considered to be the most stable solid that immobilizes arsenic in these systems [2,40,45-50]. Scorodite is completely absent as an oxidation product in São Bento, where arsenopyirite, pyrrhotite and pyrite prevail as ore minerals [33].

\section{References}

[1] Cabri, L.J., The mineralogy of precious metals: new developments and metallurgical implications. The Canadian Mineralogist, 25 (1987), 1-7.

[2] Marsden, J., House, I., The Chemistry of Gold Extraction. Ellis Horwood, New York, (1992), 579 pp.

[3] Ladeira, E.A., Gênese do ouro na mina de Morro Velho e no distrito de Nova Lima, Minas Gerais, Brasil. XXXI Congresso Brasileiro de Geologia, Camboriú, vol. 2, 1980, 371.

[4] Márquez-Godoy, M.A., Gaspar, J.C., Caracterização mineralógica do minério, concentrado e rejeito da flotação da mina São Bento (MG). In: Marini O.J. (Ed.), Caracterização de Minérios e Rejeitos de Depósitos Minerais Brasileiros. Estudos texturais, química mineral e varredura química. Resumos expandidos. Brasília, DF: DNPM/DIREX/PADCT/GTM, (1997), 9-12.

[5] Márquez-Godoy, M.A., Caracterização mineralógica do minério, concentrado e rejeito da flotação da mina São Bento (MG). Tese de Mestrado. Instituto de Geociências, Universidade de Brasília, Brasília D.F., 1995, 237 pp.

[6] Steele, I.M., Cabri, L.J., Gaspar, J.C., McMahon, G., MárquezGodoy, M.A., Vasconcellos, M.A.Z., Gold sulphides from São Bento mine; Brazil: comparative analysis by SXRF and SIMS. Canadian Mineralogist, 38 (2000), 1-10.

[7] Márquez-Godoy, M.A., Gaspar, J.C., Oro "invisible": definición, técnicas de investigación, caracterización, condiciones de formación, métodos de recuperación, ejemplo de la mina São Bento (Brasil). In: Gomez, L.S. (Ed.), Memorias del Simposio de Microscopía Electrónica Aplicada a la Investigación em Geociencias. Ingeominas, Santafé de Bogotá, D.C., 1996, 9-21.

[8] Da Silva, E.J., Haines, A.K., Carvalho, T.M., De Melo, M.P., Doyle, B.N., Process selection, design, commissioning and operation of the São Bento Mineração refractory gold ore treatment complex. Proc. of World Gold 89. AIME, 1989, 322-332. Chap. 38.

[9] Dutrizac, J.E., Kaiman, S., Synthesis and properties of jarositetype compounds. Canadian Mineralogist, 14 (1976), 151-158.

[10] Ivarson, K.C., Ross, G.J., Miles, N.M., The microbiological formation of basic ferric sulfates: II. Crystallization in presence of potassium, ammonium, and sodium-salts. Soil Science Society of America Journal, 43 (1979), 908-912.

[11] Grishin, S.I., Bigham, J.M., Tuovinen, O.H., Characterization of jarosite formed upon bacterial oxidation of ferrous sulfate in a packed-bed reactor. Applied and Environmental Microbiology, (1988 (Dec.)), 3101-3106 
[12] Addler, H.H., Kerr, P.F., Variations in infrared spectra, molecular symmetry of sulfate minerals. The American Mineralogist, 50 (1965), 132-147.

[13] Márquez-Godoy, M.A., Mineralogia dos produtos de oxidação sob pressão e bacteriana do minério de ouro da mina São Bento, MG. PhD thesis, Geoscience Intitute, Brasilia University, Brazil, 1999, 269 pp.

[14] Sasaki, K., Raman study of the microbially mediated dissolution of pyrite by Thiobacillus ferrooxidans. The Canadian Mineralogist, 35 (1997), 999-1008.

[15] Lazarov, N., Sigal, W., Wasserman, A., Iron oxidation and precipitation of ferric hydroxysulfates by resting Thiobacillus ferrooxidans cells. Applied and Environmental Microbiology, (1982 (Apr.)), 924-938.

[16] Scott, K.M., Solid solution in, and classification of, gossanderived members of the alunite-jarosite family, northwest Queensland, Australia. American Mineralogist, 72 (1987), 178-187.

[17] Dutrizac, J.E., Jambor, J.L., Chen, T.T., The behavior of arsenic during jarosite precipitation: reactions at $150{ }^{\circ} \mathrm{C}$ and the mechanism of arsenic precipitation. Canadian Metallurgical Quarterly, 26 (1987), 103-115.

[18] Kubiz, J., Studies on synthetic alkali-hydronium jarosites: I. Synthesis of jarosite and natrojarosite. Mineralogia Polonica, 1 (1970), 47-57.

[19] Alpers, C.N., Nordstrom, K.D., Ball, J.W., Solubility of jarosite solid solutions precipitated from acid mine waters, Iron Mountain, California, USA. Sciences Géologiques Bulletin, 42 (1989), 281-298.

[20] Ripmeester, J.A., Ratcliffe, C.I., Dutrizac, J.E., Jambor, J.E., Hydronium íon in the alunite-jarosite group. Canadian Mineralogist, 24 (1986), 435-447.

[21] Rimstidt, J., Chermak, J.A., Cagen, P.M., Rates of reaction of galena, sphalerite, chalcopyrite, and arsenopyrite with $\mathrm{Fe}(\mathrm{III})$ in acidic solutions. In: Alpers, C.N., Blowes, D.W., (Eds.), Environmental Geochemistry of Sulfide Oxidation. ACS Symposium Series. American Chemical Society, Washington, D.C., vol. 550, 1994, 1-13. Chap. 1.

[22] Ossa, D.M., Márquez, M.A., Biolixiviación de sulfuros (pirita arsenopirita) provenientes de la mina el Zancudo, Titiribí, Antioquia, utilizando un consorcio de microorganismos acidófilos nativos. Segundo Congreso Colombiano de Biotecnología Primer Seminario Internacional de Bionegocios, 2004.

[23] Deer, W.A., Howie, R.A., Zussman, J., An introduction to the rock forming minerals, Longman, England, 1992, 696 pp.

[24] Konhauser, K.O., Diversity of bacterial iron mineralization. Earth-Science Reviews, 43 (1998), 91-121.

[25] López-Delgado, A., Alguacil, F.J., López, F.A., Recovery of iron from bio-oxidized sulphuric pickling waste water by precipitation as basic sulphates. Hydrometallurgy, 45 (1997), 97-112.

[26] McIntosh, J.M., Silver, M., Groat, L.A., Bacteria and the breakdown of sulfide minerals. In: McIntosh, J.M., Groat, L. A., (Eds.), Biological-Mineralogical Interactions, vol. 26, Cap. 4. Mineralogical Association of Canada, Short Course Series, 1997, 63-92.

[27] Kiowasaki, K., Honbou, Y., Takaki, K., Mori, T., Experimental study on formation of jarosite and ammoniojarosite associated with Thiobacillus ferrooxidans. Earth Science, 47 (1993), 493-506.

[28] Lindström, E.B., Gunneriusson, E., Tuovinen, O.H., Bacterial oxidation of refractory sulfide ores for gold recovery. Critical Reviews in Biotechnology, 12 (1992), 133-155.
[29] Ivarson, K.C., Ross, G.J., Miles, N.M., Formation of rubidium jarosite during the microbiological oxidation of ferrous iron at room temperature. Canadian Mineralogist, 43 (1981), 429-434.

[30] Leduc, L.G., Bacteria: an introduction. In: McIntosh JM, Groat LA, (Eds.), Biological-Mineralogical Interactions, vol. 26, Cap. 1. Mineralogical Association of Canada, Short Course Series, 1997, 1-14.

[31] Niemelä, S.I., Riekkola-Vanhanen, M., Sivelä, C., Viguera, F., Tuovinen, O.H., Nutrient effect on the biological leaching of a black-schist ore. Applied and Environmental Microbiology, (1994), 1287-1291.

[32] Dutrizac, J.E., Jambor, J.L., The behavior of arsenic during jarosite precipitation: arsenic precipitation at $97^{\circ} \mathrm{C}$ from sulphate or chloride media. Canadian Metallurgical Quarterly, 26 (1987), 91-101.

[33] Tuovinen, O.H., Bhatti, T.M., Bigham, J.M., Hallberg, K.B., Garcia Jr., O., Lindström, E.B., Oxidative dissolution of arsenopyrite by mesophilic and moderately thermophilic acidophiles. Applied and Environmental Microbiology, (1994), 3268-3274.

[34] Jones, C.A., Inskeep, W.P., Neuman, D.R., Arsenic transport in contaminated mine tailings following liming. Journal of Environmental Quality, 26 (1997), 433-439.

[35] Nordstrom, D.K., Alpers, C.N., Geochemistry of acid mine waters. In: Plumlee GS, Logsdon MJ, (Eds.), The environmental geochemistry of mineral deposits. Reviews in Economic Geology. Society of Ecologic Geologists, 1998.

[36] Edwards, K.J., Schrenk, M.O., Hamers, R., Banfield, J.F., Microbial oxidation of pyrite: experiments using microorganism from an extreme acidic environment. American Mineralogist, 83 (1998), 1444-1453

[37] Das, G.K., Anad, S., Acharya, S., Das, R.P., Characterization and acid pressure leaching of various nickel-bearing chromite overburden samples. Hydrometallurgy, 44 (1997), 97-111.

[38] Das, G.K., Anad, S., Acharya, S., Das, R.P., Preparation and decomposition of ammoniojarosite at elevated temperatures in $\mathrm{H}_{2} \mathrm{O}-\left(\mathrm{NH}_{4}\right)_{2} \mathrm{SO}_{4}-\mathrm{H}_{2} \mathrm{SO}_{4}$ media. Hydrometallurgy, 38 (1995), 263-276.

[39] Nesbitt, H.W., Muir, I.J., Oxidation states and speciation of secondary products on pyrite and arsenopyrite reacted with mine waste waters and air. Mineralogy and Petrology, 62 (1998), 123-144.

[40] Filippou, D., Demopoulos, G.P., Arsenic immobilization by controlled scorodite precipitation. JOM, (1997 (December)), $52-55$.

[41] Vink, B.W., Stability relations of antimony and arsenic compounds in the ligh of revised and extended $\mathrm{Eh}-\mathrm{pH}$ diagrams. Chemical Geology, 130 (1996), 21-30.

[42] Papangelakis, V.G., Demopoulos, G.P., Acid pressure oxidation of arsenopyrite: Part I. Reaction chemistry. Canadian Metallurgical Quarterly, 29 (1990), 1-12.

[43] Carlson, L., Lindström, E.B., Hallberg, K.B., Tuovinen, O.H., Solid-phase products of bacterial oxidation of arsenical pyrite. Applied and Environmental Microbiology (1992), 1046-1049.

[44] Daus, B., Weib, H., Wennrich, R., Arsenic speciation in iron hydroxide precipitartes. Talanta, 46 (1998), 867-873.

[45] Baghurst, D.R., Barrett, J., Mingos, M.P., The hydrothermal microwave synthesis of scorodite: Iron(III), Arsenate(V) Dihydrate, $\mathrm{FeAsO}_{4} \cdot 2 \mathrm{H}_{2} \mathrm{O}$. Journal of the Chemical Society, Chemical Communications, (1995), 323-324.

[46] Foster, A.L., Brown Jr., G.E., Parks, G.A., Tingle, T.N., Voigt, D.E., Brantley, S.L., XAFS determination of As(V) associated 
with $\mathrm{Fe}(\mathrm{III})$ oxyhydroxides in weathered mine tailings and contaminated soil from California, USA. J Phis IV France, Colloque C2, 7 (1997), C2-815-C2-816.

[47] Demopoulos, G.P., Droppert, D.J., Van Weert, G., Precipitation of crystalline scorodite $\left(\mathrm{FeAsO}_{4} \cdot 2 \mathrm{H}_{2} \mathrm{O}\right)$ from chloride solutions. Hydrometallurgy, 38 (1995), 245-261.

[48] Van Weert, G.V., Droppert, D.J., Aqueous processing of arsenic trioxide to crystalline scorodite. JOM (1994), 36-38.
[49] Kunter, R.S., Bedal, W.E., Chloride-process treatment of smelter flue dusts. JOM (1992), 35-38.

[50] Dutrizac, J.E., Jambor, J.L., The synthesis of crystalline scorodite, $\mathrm{FeAsO}_{4} \cdot 2 \mathrm{H}_{2} \mathrm{O}$. Hydrometallurgy, 19 (1988), 377-384. 